\title{
Corporate Characteristics of Retailing Companies among Malaysia, Japan and USA
}

\author{
Nurul Zarirah Nizam ${ }^{1,2} \&$ Yasuo Hoshino ${ }^{1,3}$ \\ ${ }^{1}$ Graduate School of Business Administration, Aichi University, Nagoya, Japan \\ ${ }^{2}$ Faculty of Technology Management \& Technopreneurship, University of Technical Malaysia Melaka, Malaysia \\ ${ }^{3}$ Institute of Policy and Planning Sciences, University of Tsukuba, Tsukuba, Japan \\ Corresponding: Nurul Zarirah Nizam, Graduate School of Business Administration, Aichi University, 2-10-31 \\ Tsutsui Higashi-ku Nagoya, 461-8641, Japan. Tel: 81-90-4261-4444. E-mail: zarirah@utem.edu.my
}

Received: March 23, 2015

Accepted: April 7, $2015 \quad$ Online Published: May 22, 2015

doi:10.5539/ijbm.v10n6p40

URL: http://dx.doi.org/10.5539/ijbm.v10n6p40

\begin{abstract}
This study reviews critically the performance of financial ratios in retail industry. The data obtained from OSIRIS database was analysed by Statistical Package for Social Sciences (SPSS) software version 22 (Test of normality, Kruskal-Wallis Test, Comparison of means, Correlation and Regression Analysis). Our main findings showed that retailing companies in Malaysia contribute high means value for ROCE, ROA, profit margin, current ratio, liquidity ratio, solvency ratio and number of employees. While Japan showed the highest means value of sales growth rate and USA showed high means value of ROE, market capitalization, number of shareholders, and number of subsidiaries over the period 2008-2012. The results support the first hypothesis which stated that, sales growth rate of retail companies in Japan is better than the USA. While, the results did not contribute to the second hypothesis, which stated that Japan and USA have a successful performance of financial ratios compared to Malaysia. Lastly, the results support our third hypothesis; the corporate variables influence the performance of financial ratios of the retailing companies.
\end{abstract}

Keywords: retailing industry, profitability ratios, financial performance, developed countries, developing countries

\section{Introduction}

Retail is the sale of goods to end users, not for resale, but for use and consumption by the purchaser. The retail transaction is at the end of the supply chain. Manufacturers sell large quantities of products to retailers, and retailers attempt to sell those same quantities of products to consumers. Many studies have been conducted to examine retailing of developing countries, the results varied significantly. Some studies focused on a single nation or a particular channel member, whereas others have provided cross-cultural insights. The importance of profitability ratios is explored by defining the return on capital equity (ROE), return on assets (ROA), return on capital employed (ROCE), liquidity ratio, solvency ratio, current ratio and sales growth rate in the retailing industry, and it is quite interesting because the results will contribute into EVA in the future (Rayley \& Benton, 2010).

Retailing 2015 confirms that the retail industry is becoming more complex and changing at an ever-increasing speed. The evolving consumer in the near future will not be easy for retailers to understand or master. Consumers are increasingly proactive in their purchase decisions and selective about with whom they want to do business. Additionally, consumers will increase their focus on purchasing products from socially responsible and "green friendly" manufacturers and retailers (PWC, 2015).

\subsection{Growing Competition in Retailing}

Kearney (2014), Malaysia have upgraded full-year GDP forecast from the previous $4.5 \%$ to $5.8 \%$ on the back of increased domestic consumption, which bodes well for the continuing health of the retail market, particularly areas such as furnishing \& home. However, the retail market is expected to temporarily soften with the implementation of the Goods and Services Tax on April 1, 2015. Malaysia provides a comprehensive forecast of various retail indicators including household spending and headline total spending across each retail subsector such as household income and employment forecasts, demographic forecasts, and a detailed breakdown of 
household and per capita spending across a large number of retail areas, including food \& drink, clothing \& footwear, household goods, and a number of other subsectors. Moreover, retail sectors such as fashion, furnishings and electronics are all flourishing, with recent entrants to the market including brand like Superdry and Cath Kidston. Department stores Galaries Lafayette and Takashimaya are also reported to be planning launches in Malaysia by 2015. At the same time, food chains such as GCH Retail and The Store Corporation are expanding their product ranges to include home appliances in order to take advantage of the trend towards non-essential purchasing. Online retail is growing with more broadband adoption, a young, growing working population, and large modern retailers' efforts for online development. Worth \$1 billion in 2012, Malaysia's online retail market could nearly triple in size by 2017 .

Retail is one of the largest sectors in many national economies. Countries differ in how they define the industry, "retail is universally understood as the final step in the distribution process, in which retailers are organized to sell merchandise in small quantities to the public." This differs from wholesale trade, where firms sell to other firms. The industry is highly globalized, with large retailers operating in almost every country. The top 250 retailers are based in all regions (though dominated by European and U.S. firms). While the industry has seen the largest growth in the least developed economies, the bulk of goods are still sold in Europe and North America. Retail in 2015 will continue to be driven by the needs and preferences of two prominent generations such as baby boomers and millennial. As consulting firm PwC noted, "The Baby Boomer generation will age with increased financial resources and with a greater emphasis on youth and vitality than previous generations. As a result, they not only will tax manufacturers to adapt products to their specific post-retirement needs, but also will require retailers to respond to their evolving needs as they approach the age of 70 in 2015" (PWC, 2015).

The retailers that will move ahead of the pack in 2015 will differentiate themselves by capturing consumers at the start of their shopping journeys with an appealing presence across all digital platforms and by providing a seamless, holistic online and in store shopping experience, one that encompasses not only product assortment, pricing, shipping, return options, and promotions, but also a consistent aesthetic look and emotional feel. Effective and relevant data mining and analysis, especially to improve customer service also remains a growth opportunity for retailers (Paul, 2014).

In the other hand, according to Bjorson (2013) Japan is the second largest B2C e-commerce market in the world after USA. Japanese retailers such as Rakuten, which provides a wide range of internet services, and Aeon Co., Japan's biggest multi-channel supermarket chain, have been expanding their distribution networks to meet growing sales. Wal-Mart in Japan has experienced a reverse problem that arises from branding. While Japan consumers at Seiyu stores had not noticed price changes in the food category. But they recognized lower prices offered in the apparel category since Wal-Mart's entry (Brunn, 2015).

In Japan, According to Kudo (2014), Japan's biggest retail group by revenue, Aeon Co. has put nearly 3,000 automatic checkers in hundreds of stores nationwide. Wal-Mart Stores Inc.'s Japan subsidiary plans to more than double the number in its stores in 2015. It was a different story when USA whose based retailer started in Japan by forging a partnership with Seiyu, Ltd., a national grocery chain that was also experiencing difficult times. Known for its wide selection of products and low prices, Wal-Mart didn't catch the Japanese market as quickly as it had hoped, attributing it to traditional consumer attitudes that looked down on discount prices as a sign of poor quality. Undoubtedly, the Asian retail market is projected to expand to $\$ 5$ trillion by 2020 . Aeon Co. posted total sales of around 6.4 trillion yen in fiscal 2013. It has around 260 consolidated subsidiaries in Japan and abroad and has 420,000 employees including part-timers. Aeon plans to invest roughly 1.5 trillion yen in the three-year period from fiscal 2014, which started this March, 2015. Asia is projected to overtake the United States to become the world's largest market in 2020, with estimated combined gross domestic product of $\$ 20$ trillion.

Besides that, retail industries situation in USA where, the sum total of all store openings scheduled to happen in the 2014 calendar year by the largest USA retail industry chains doesn't just equal USA retail industry growth, it also figures into the equation for overall economic stability in the USA and around the world. The reason there is so much significance attached to the USA based retail and restaurant chain new store openings in 2014 is because those USA retail store openings are not just happening domestically, they are also happening internationally. As has been the case in the past couple of years, a significant percentage of new store locations planned by USA retail companies will be worldwide store openings (Farfan, 2014).

Nevertheless, this study is an attempt to shed light on financial ratios that contribute to small or big influence to the economy in each selected country (Malaysia, Japan and the USA). In this study, related data from OSIRIS database was used, which highlighted the financial ratios and corporate variables over 2008-2012. OSIRIS 
database is a fully integrated public company database and analytical information solution produced by Bureau van Dijk Electronic Publishing, SA (BvD). By working with specialist data providers from around the world, BvD makes OSIRIS as the most accurate, comprehensive and user-friendly information tool available for the world's public companies.

\section{Literature Review}

In this research, profitability ratios focused on profit margin, return on shareholders' funds (ROE), return on total assets (ROA) and return on capital employed (ROCE). A profitability ratio is a measure of profitability, which is a way to measure a company's performance. According to (Ross et al., 2005), accounting profits are the difference between revenues and costs. Profitability is considered to be the most difficult attributes of a firm to conceptualize and to measure. These ratios are used to assess the ability of the business to generate earnings in comparison with its all expenses and other relevant costs during a specific time period. More specifically, these ratios indicate firm's profitability after taking account of all expenses and income taxes, the efficiency of operations, firm pricing policies, profitability on assets and to shareholders of the firm.

Yap et al. (2012) acknowledged, companies in Malaysia do not have as long a history as those in the Western countries and their sizes are, for most of the companies, not as large. In addition, their access to funds and capital are not as easily available compared to the more developed countries. The development of the capital market in Malaysia is still at its early stages compared to advanced markets in the West. Although the government has always been stressing the importance of good corporate governance, Malaysia has not been immune to corporate collapses and scandals. Therefore, the selection of financial ratios and the predictive models and their statistical techniques used in researches done elsewhere may not be as applicable or as reliable and accurate as when they are applied to the Malaysian companies.

Profitability is measured by return on equity, return on assets, and return on investment. Asset management is measured by receivable turnover, total asset turnover, and inventory turnover (Asheghian, 2012). Traditional financial indicators are the most common used financial ratios in the performance evaluation that are usually related to profitability (Yalcin et al., 2012). Balance sheet and data in income statement from financial ratios considered as critical measurement tools in determining financial assets of companies and performance. Financial performance concept is considered under different meanings such as productivity, return, economic and output growth, using the financial ratios for both companies and related sectors can be suitable for performance evaluation (Yalcin et al., 2012). Varaiya et al. (1987) examined how value-based planning performs as an evaluation of corporate strategies. They conclude that the expected spread, the difference between return on equity and the cost of capital, and the expected earnings growth are positively related to firm market value. The results also reveal that the former is more important than the latter for firm value which implies that growth have less importance in creating value than anticipated.

Comprehensive financial performance is becoming increasingly important as an indicator of corporate performance companies. This configuration of the company performance is much more adherent with the market reality rather than the industry itself. For this reason, the investor companies, in the evaluation of investments, should use the indicator ROE and other related profitability ratios, where shows the performance impact much more clearly and providing better information for users and particular for partnerships and investors of the companies (Gazzola \& Amelio, 2014). In addition, according to Sam and Hoshino (2013), sales growth rates denote a percentage change in the sales of a company in a given years with the respect to the previous year sales. It tells whether the company's sales increase or decrease during a specific year and also tells the size of change.

Besides that, the most commonly used measure of retail productivity is labour productivity (Higon et al., 2010), the ratio between a measure of output (frequently sales or gross value added) and a measure of labour (the number of employees or man-hours worked). It is of course vulnerable to the implicit assumption that there is only a single factor of production, labours, and ignores the role of physical capital, land and other factors.

In this study, we focusing on developing country which can be define as a term generally used to describe a nation with a low level of well-being (not to be confused with third world countries). Since no single definition of the term developed country is recognized internationally, the levels of development may vary widely within so-called developing countries. Some developing countries have high average standards of living (Korotayev et al., 2011). Globalization and expanding international markets as well as the fast-growing middle and high income classes in many developing countries offer opportunities for developing country retailer to operate in emerging national and international markets.

This study focused financial performance factors and corporate variables, which is defined as the financial statement analysis as an information processing system that is designed to provide data for decision makers 
(Norman, 2011). The information is basically derived from published financial statements, but in the analysis process, it is also made for non-accounting data such as stock prices and aggregate economic indicators. Financial Statement Analysis is an essential tool for making an informed decision. He also asserted that financial analysis is used in evaluating a company's economic situation and predicting its future course for various reasons, including investment purposes since its importance will be increased when it is used as a determinant for investing.

\section{Hypothesis of the Study}

Based on Sam and Hoshino (2013) study, sales growth rate generally utilizes capacity more fully, which spreads fixed costs over more revenue resulting in higher profitability. If an industry has increasing economies of scale or learning curve effects, growing firms benefit from such effects, again increasing performance. They also stated that, to reach their financial objectives effectively, firms must use a wide diversity of goals, including sales growth rate. While, in order to know the financial performances of developed country and developing country different ratios are applied and being tested. This is very important to look up the financial performance and make superior allocation for improving efficiency for the coming time. In this study, the hypotheses are as follows:

Hypothesis 1: Sales growth rate of retail companies in Japan is better than the USA.

Hypothesis 2: Japan and USA have a successful performance of financial ratios compared to Malaysia.

Hypothesis 3: The number of shareholders influences the performance of ROE of the retailing companies.

\section{Methodology}

The study proceeds with the following steps regarding financial statement analysis. Data was gathered through annual reports of the listed companies from OSIRIS database. The numerical data was extracted from the recent five years (2008 to 2012) of financial ratios and corporate variables of the listed companies. Then the data has been analysed by Statistical Package for Social Sciences (SPSS) software version 22 for Test of normality, Kruskal-Wallis Test, Comparison of means, Correlation and Regression analysis.

\subsection{Variable Definitions}

- Profitability Ratios

Profit Margin = Profit Before Tax/Operating Revenue* 100

Return on Shareholders' Funds (ROE) $=$ Profit Before Tax/Shareholders Funds) * 100

Return on Total Assets $(\mathrm{ROA})=$ Profit Before Tax / Total Assets $) * 100$

Return on Capital Employed $($ ROCE) $=$ Profit Before Tax - Interest Expenses)/ (Shareholder Funds + Non-Current Liabilities) * 100

- Safety Ratios

Current Ratio $=$ Current Assets $/$ Current Liabilities

Liquidity Ratio $=$ Current Assets - Stocks $/$ Current Liabilities

Solvency Ratio $=($ Shareholders Funds $/$ Total Assets $) * 100$

\subsection{Sample}

The sample includes 16 companies from Malaysia, 64 companies from Japan and 54 companies from USA. The listed companies of three countries are shown in Appendix A. As previously mentioned, the data for the performance of the companies was derived from the OSIRIS Database. The criteria for inclusion of firms in the sample are as follows:

i. We only selected firms that show all financial data that we use in this research, and complete within the year of 2008 to 2012 . Some companies with $80 \%$ of missing data were eliminated from the sample.

ii. We only selected retailing industry companies of these three countries and excluded all other types of business industries from the OSIRIS Database. 


\section{Results and Discussion}

Table 1 . Tests of normality among three countries of financial ratios

\begin{tabular}{|c|c|c|c|c|c|c|c|}
\hline \multirow{2}{*}{ Financial Ratios } & \multirow[t]{2}{*}{ Country } & \multicolumn{3}{|c|}{ Kolmogorov-Smirnov ${ }^{\mathrm{a}}$} & \multicolumn{3}{|c|}{ Shapiro-Wilk } \\
\hline & & Statistic & df & Sig. & Statistic & $\mathrm{df}$ & Sig. \\
\hline \multirow{3}{*}{ ROE } & Malaysia & .147 & 16 & $.200^{*}$ & .916 & 16 & .148 \\
\hline & Japan & .085 & 64 & $.200^{*}$ & .975 & 64 & .208 \\
\hline & USA & .226 & 54 & .000 & .763 & 54 & .000 \\
\hline \multirow{3}{*}{ ROCE } & Malaysia & .111 & 16 & $.200^{*}$ & .951 & 16 & .498 \\
\hline & Japan & .136 & 64 & .005 & .916 & 64 & .000 \\
\hline & USA & .057 & 54 & $.200^{*}$ & .987 & 54 & .808 \\
\hline \multirow{3}{*}{ ROA } & Malaysia & .163 & 16 & $.200^{*}$ & .910 & 16 & .116 \\
\hline & Japan & .128 & 64 & .011 & .931 & 64 & .001 \\
\hline & USA & .050 & 54 & $.200^{*}$ & .982 & 54 & .591 \\
\hline \multirow{3}{*}{ Profit Margin } & Malaysia & .168 & 16 & $.200^{*}$ & .931 & 16 & .255 \\
\hline & Japan & .169 & 64 & .000 & .897 & 64 & .000 \\
\hline & USA & .128 & 54 & .027 & .890 & 54 & .000 \\
\hline \multirow{3}{*}{ Current Ratio } & Malaysia & .293 & 16 & .001 & .798 & 16 & .003 \\
\hline & Japan & .141 & 64 & .003 & .908 & 64 & .000 \\
\hline & USA & .201 & 54 & .000 & .633 & 54 & .000 \\
\hline \multirow{3}{*}{ Liquidity Ratio } & Malaysia & .227 & 16 & .027 & .784 & 16 & .002 \\
\hline & Japan & .134 & 64 & .006 & .900 & 64 & .000 \\
\hline & USA & .260 & 54 & .000 & .488 & 54 & .000 \\
\hline \multirow{3}{*}{ Solvency Ratio } & Malaysia & .106 & 16 & $.200^{*}$ & .974 & 16 & .905 \\
\hline & Japan & .070 & 64 & $.200^{*}$ & .980 & 64 & .380 \\
\hline & USA & .089 & 54 & $.200^{*}$ & .979 & 54 & .462 \\
\hline \multirow{3}{*}{ Sales Growth Rate } & Malaysia & .103 & 16 & $.200^{*}$ & .968 & 16 & .798 \\
\hline & Japan & .175 & 64 & .000 & .794 & 64 & .000 \\
\hline & USA & .209 & 54 & .000 & .830 & 54 & .000 \\
\hline
\end{tabular}

Notes. Sample size Malaysia $=16$, Japan $=64, \mathrm{USA}=54 ; *$ This is a lower bound of the true significance. a. Lilliefors Significance Correction.

Table 2. Tests of normality among three countries of corporate variables

\begin{tabular}{|c|c|c|c|c|c|c|c|}
\hline & \multirow{2}{*}{ Country } & \multicolumn{3}{|c|}{ Kolmogorov-Smirnov ${ }^{\mathrm{a}}$} & \multicolumn{3}{|c|}{ Shapiro-Wilk } \\
\hline & & Statistic & df & Sig. & Statistic & df & Sig. \\
\hline \multirow{3}{*}{ Market Capitalization } & Malaysia & .279 & 16 & .002 & .619 & 16 & .000 \\
\hline & Japan & .334 & 64 & .000 & .410 & 64 & .000 \\
\hline & USA & .334 & 54 & .000 & .469 & 54 & .000 \\
\hline \multirow{3}{*}{$\begin{array}{l}\text { Number } \\
\text { Shareholders }\end{array}$} & Malaysia & .160 & 16 & $.200^{*}$ & .946 & 16 & .434 \\
\hline & Japan & .111 & 64 & .050 & .962 & 64 & .045 \\
\hline & USA & .140 & 54 & .010 & .939 & 54 & .008 \\
\hline \multirow{3}{*}{ Number of Subsidiaries } & Malaysia & .203 & 16 & .077 & .866 & 16 & .023 \\
\hline & Japan & .161 & 64 & .000 & .888 & 64 & .000 \\
\hline & USA & .283 & 54 & .000 & .635 & 54 & .000 \\
\hline \multirow{3}{*}{ Number of Employees } & Malaysia & .424 & 16 & .000 & .335 & 16 & .000 \\
\hline & Japan & .331 & 64 & .000 & .583 & 64 & .000 \\
\hline & USA & .371 & 54 & .000 & .315 & 54 & .000 \\
\hline
\end{tabular}

Notes. Sample size Malaysia $=16$, Japan $=64, \mathrm{USA}=54 ; *$ This is a lower bound of the true significance. a. Lilliefors Significance Correction. 
Table 3. Pairwise comparisons results for the Tukey post hoc test

\begin{tabular}{llllll}
\hline Country & Variables & Mean Square & df & F & Sig. \\
\hline $\begin{array}{l}\text { Malaysia } \\
\text { Japan }\end{array}$ & ROE & 1804.633 & & 19.061 & .000 \\
$\begin{array}{l}\text { Malaysia } \\
\text { USA }\end{array}$ & ROCE & 871.333 & & 38.964 & .000 \\
$\begin{array}{l}\text { Malaysia } \\
\text { USA }\end{array}$ & ROA & 385.919 & 2 & 32.291 & .000 \\
$\begin{array}{l}\text { Malaysia } \\
\text { Japan }\end{array}$ & Solvency ratio & & & & \\
USA & & 1690.754 & 7.184 & .001 \\
\hline
\end{tabular}

Notes. The variables have been taken by referring the normality test from Table 1 (looking at the asterisk $\left({ }^{*}\right)$ which indicated a lower bound of the true significance).

From Table 1, with the symbol of asterisk $\left({ }^{*}\right)$ show a non-significant value of .200 which includes ROE of Malaysia and Japan, ROCE of Malaysia and USA, ROA of Malaysia and USA, Profit Margin of Malaysia, Solvency Ratio of all three countries and sales growth rate of Malaysia. In this study, we only have $\mathrm{N}=16$ of Malaysia samples which is very small in size compared to Japan $(\mathrm{N}=64)$ and USA $(\mathrm{N}=54)$. For the other data, the test is highly significant, indicating that this distribution is not normal. Table 2 indicates only number of shareholders of Malaysia stated non-significant value of .200. However the other variables showed highly significant.

Table 3 indicates the pairwise comparisons to determine which groups differed from each other. There was a statistically significant difference between groups as determined by one-way ANOVA. A Tukey post-hoc test revealed that profitability was statistically significantly higher in ROCE $(F=38.964)$ and ROA $(F=32.291)$ between Malaysia and USA compared to Malaysia and Japan or Japan and USA. However, analysis for ROE showed that Malaysia and Japan was statistically significantly with $F=19.061$. While, solvency ratio recorded there was a statistically significant difference among Malaysia, Japan and USA with the value of $F=38.964$.

Table 4. Comparisons of financial ratios among three countries using Kruskal-Wallis test

\begin{tabular}{llllllllll}
\hline \multicolumn{1}{c}{ Statistics $^{\mathbf{a , b}}$} & & & & & & & \\
& & ROE & ROCE & ROA & $\begin{array}{l}\text { Profit } \\
\text { Margin }\end{array}$ & $\begin{array}{l}\text { Current } \\
\text { Ratio }\end{array}$ & $\begin{array}{l}\text { Liquidity } \\
\text { Ratio }\end{array}$ & Solvency RatioSales Growth Rate \\
\hline Country/ & Malaysia & 16.68 & 15.34 & 9.96 & 10.75 & 2.59 & 1.77 & 59.74 & 1.64 \\
Mean & Japan & 7.91 & 6.15 & 3.51 & 4.30 & 1.15 & .79 & 43.49 & 6.72 \\
& USA & 18.69 & 12.51 & 7.53 & 6.16 & 2.01 & .94 & 46.57 & 3.13 \\
Chi-Square & & 44.006 & 54.091 & 46.188 & 17.966 & 38.487 & 5.759 & 10.033 & 22.061 \\
df & 2 & 2 & 2 & 2 & 2 & 2 & 2 & 2 \\
Asymp. Sig. & .000 & .000 & .000 & .000 & .000 & .056 & .007 & .000 \\
\hline
\end{tabular}

Notes. Sample size Malaysia $=16$, Japan $=64, \mathrm{USA}=54$;

a. Kruskal Wallis Test;

b. Grouping Variable: country. 
Table 5. Comparisons of corporate variables among three countries using Kruskal-Wallis test Statistics ${ }^{\mathrm{a}, \mathrm{b}}$

\begin{tabular}{|c|c|c|c|c|c|}
\hline & & $\begin{array}{l}\text { Market Capitalization } \\
\text { (US in million) }\end{array}$ & $\begin{array}{l}\text { Number of } \\
\text { Shareholders }\end{array}$ & $\begin{array}{ll}\text { Number } & \text { of } \\
\text { Subsidiaries }\end{array}$ & Number of Employees \\
\hline Country/ & Malaysia & 205 & 22 & 11 & 113049 \\
\hline \multirow[t]{2}{*}{ Mean } & Japan & 4598 & 24 & 21 & 8917 \\
\hline & USA & 19319 & 77 & 25 & 102154 \\
\hline Chi-Square & & 37.805 & 72.475 & 4.212 & 35.024 \\
\hline df & & 2 & 2 & 2 & 2 \\
\hline Asymp. Sig & & .000 & .000 & .122 & .000 \\
\hline
\end{tabular}

Notes. Sample size Malaysia $=16$, Japan $=64, \mathrm{USA}=54$;

a. Kruskal Wallis Test;

b. Grouping Variable: country.

Kruskal-Wallis test is a non-parametric method for testing whether samples originate from the same distribution. It is used for comparing two or more samples that are independent and that may have different sample sizes (Field, 2013). Table 4 showed that there was a statistically significant difference in all financial ratios available among Malaysia, Japan and USA except for liquidity ratio with $p=.056$.

From Table 4, we can see the mean value for ROE for those three countries separately starting with Malaysia, 16.68, Japan, 7.91 and USA, 18.69. Obviously USA showed the highest mean value compared to other country in this industry. ROE is widely used by investors to measure the company's earnings performance. The ROE tells common shareholders how effectively their money is being employed. Higher ratios are almost always better than lower ratios, but have to be compared to other companies' ratios in the same industry. Since every industry has different levels of investors and income, ROE cannot be used to compare companies outside of their industries very effectively.

Next, ROCE is an important measure of a company's profitability. Many investment analysts especially think that factoring debt into a company's total capital provides a more comprehensive evaluation on how well management is using the debt and equity it has at its disposal. In this regard, we have analysed the results of the listed companies which showed Malaysia with the mean value of 15.34, USA (12.51) and Japan (6.15). This means, Malaysia represent a better understanding of a company's ability to generate returns from its available capital base compared to Japan and USA over the period.

ROA ratio illustrates how well management is employing the company's total assets to make a profit. The higher the return, the more efficient management is in utilizing its asset base. The ROA ratio is calculated by comparing net income to average total assets, and is expressed as a percentage. For this reason, we could consider this analysis of ROA among Malaysia, Japan and USA with their own different-sized asset bases, product line and business type showed difference value of mean different. Basically, the mean value of ROA for Malaysia (9.96) showed the highest compared to others followed with USA (7.53) and Japan (3.51). ROA gives an indication of the capital intensity of the company, which will depend on the industry itself or companies that require large initial investments will generally have lower return on assets.

Profit margin indirectly measures how well a company manages its expenses relative to its net sales. That is why companies strive to achieve higher ratios. They can do this by either generating more revenues why keeping expenses constant or keep revenues constant and lower expenses. Like most profitability ratios, this ratio is the best to compare like sized companies in the same industry. This ratio is also effective for measuring past performance of a company. In other words, outside users want to know that the company is running efficiently. An extremely low profit margin would indicate the expenses are too high and the management needs to budget and cut expenses. The return on sales ratio is often used by internal management to set performance goals for the future. In this study, Malaysia showed the highest of mean value compared to USA and Japan with the value of $10.75,6.16$ and 4.30 respectively.

A large amount of current assets in relationship to a small amount of current liabilities provides some assurance that the obligations coming due will be paid. For mean value Malaysia represents 2.59, then USA (2.01) and lastly is Japan (1.15) where would consider a high current ratio to be better than a low current ratio, because a high current ratio means that the company is more likely to meet its liabilities which fall due in the next 12 months. 
Besides, liquidity ratios can give investors an idea of how capable a company will be at raising cash to purchase additional assets or to repay creditors quickly, either in an emergency situation, or in the course of normal business. In the case of this ratio, Malaysia indicates the highest, and then USA and lastly Japan with the value of $1.77,0.94$ and 0.79 respectively. This mean that the companies listed in Malaysia have and high ability to pay its short-term debts. There are three common calculations that fall under the category of liquidity ratios. The current ratio is the most liberal of the three. It is followed by the acid ratio, and the cash ratio. These three ratios are often grouped together by financial analysts when attempting to accurately measure the liquidity of a company.

Measuring cash flow rather than net income is a better determinant of solvency, especially for companies that incur large amounts of depreciation for their assets but have low levels of actual profitability. So, from Table 4 we could consider Malaysia showed the higher mean value followed by Japan and USA, and Japan with 59.74, 43.49 and 46.57 respectively. Different countries will use different methodologies to calculate the solvency ratio, and have different requirements. For example, in India insurers are required to maintain a minimum ratio of 1.5 (Wikipedia.org). A number of financial ratios are used to measure a company's solvency, and an investor should use both sets to get the complete picture of a company's financial position. Additional useful information can be gleaned by comparing a company's ratios versus its peers and by analysing ratio trends of the industry itself.

Sales growth rate is defined as the amount by which the average sales volume of a company's products or services has grown, typically from year to year. As shown in the data, sales growth rate refers of five years date of incorporation. The selected year was from 2008 to 2012. A note to be considered is that the amount a company derives from sales compared to a previous, corresponding period of time, in which the latter sales exceed the former. For example, a company experienced sales growth rate when its sales were $\$ 1$ million in 2008 and $\$ 1.5$ million in 2009. Sales growth rate considered positive for a company's survival and profitability. It may result in increased shareholders or higher stock prices as well. For mean value indicates, Japan calculated the highest number with 6.72 , followed by USA 3.13 and lastly Malaysia 1.64. Japan listed companies have grown well in these 5 years.

While, for Table 5, three corporate variables showed that there was a statistically significant difference among Malaysia, Japan and USA with market capitalization $(p=.000)$, number of shareholders $(p=.000)$, and number of employees $(p=.000)$. Besides, there were no significant differences among countries in terms of number of subsidiaries with $p=.122$. The mean value for USA of market capitalization calculated the highest compared to Japan and Malaysia with the value of \$19319 million, \$4598 million and \$205 million respectively. Market capitalization reflects only the equity value of a company. It is important to note that a firm's choice of capital structure has a significant impact on how the total value of a company is allocated between equity and debt at the current year available. Market capitalization indicates the total market value of all of a company's outstanding shares. Usually company or investment community will use this analysis to determine a company's size, as opposed to sales or total asset size basic as determinant of asset allocation and risk-return parameters for stocks and stock mutual funds. It is a general misconception that a higher stock price indicates a larger company. The classification of companies into individual capitalization also allows investors to determine the growth against risk potential. Previously, the large capitalization has faced slower growth with lower risk. Conversely, small capitalization has faced higher growth potential with a higher risk level.

Shareholders are considered by some to be a subset of stakeholders, which may include anyone who has a direct or indirect interest in the business entity. For example, employees, suppliers, customers, the community, are typically considered stakeholders because they contribute value and/or are impacted by the corporation. From Table 5, we can see USA indicated the highest mean value with 25 compared to Japan and Malaysia. The mean value for number of subsidiaries showed, USA represents the highest value with 77, followed by Japan (24) and Malaysia (22). Beside, Malaysia showed 113049, followed by USA with 102154 and Japan with 8917 for the variable of number of employees.

A subsidiary is a company that is owned or controlled by another company. The subsidiary can be a company, corporation, or limited liability company. In some cases it is a government or state-owned enterprise. The controlling entity is called its parent company, parent, or holding company (Investopedia.com). While, number of employees will show how they are gaining competitive advantage through establishing metrics and practices to effectively quantify and improve the impact of their engagement initiatives on overall business performance. These are among the findings of a new Harvard Business Review Group (2013) of more than 550 executives around employee engagement where research that features in-depth interviews with 12 best-practice company leaders. The research found that while most leaders understand the importance of engagement, three-quarters of those surveyed said that most employees in their organizations are not highly engaged. The survey found that many companies find it challenging to measure engagement and tie its impact to financial results: fewer than 50 
per cent of companies said that they are effectively measuring employee engagement against business performance metrics such as customer satisfaction or increased market share.

Although, as we have seen, it is difficult to provide a clear of central tendency of variables (mean) due to different size of company and market situation at each country even in a same industry. However, from the results of the analysis which provide the means for every variable could give us an idea to evaluate the condition of the industry itself at their country over the period 2008 to 2012.

Table 6. Correlations of all variables among three countries

\begin{tabular}{|c|c|c|c|c|c|c|c|c|c|c|c|c|}
\hline & $(1)$ & $(2)$ & (3) & (4) & (5) & (6) & $(7)$ & $(8)$ & (9) & $(10)$ & (11) & (12) \\
\hline (1) $\mathrm{ROE}$ & 1 & & & & & & & & & & & \\
\hline (2) ROCE & $.777^{* *}$ & 1 & & & & & & & & & & \\
\hline (3) $\mathrm{ROA}$ & $.689^{* *}$ & $.912^{* *}$ & 1 & & & & & & & & & \\
\hline Profit margin & $.404^{* *}$ & $.565^{* *}$ & $.674^{* *}$ & 1 & & & & & & & & \\
\hline Current ratio & .065 & $.201^{*}$ & $.367^{* *}$ & $.291^{* *}$ & 1 & & & & & & & \\
\hline Liquidity ratio & .010 & .094 & $.255^{* *}$ & $.210^{*}$ & $.883^{* *}$ & 1 & & & & & & \\
\hline (7)Solvency ratio & $-.210^{*}$ & .122 & $.377^{* *}$ & $.349^{* *}$ & $.586^{* *}$ & $.492^{* *}$ & 1 & & & & & \\
\hline (8)Sales growth rate & -.111 & $-.187^{*}$ & $-.197^{*}$ & -.130 & -.086 & .030 & -.079 & 1 & & & & \\
\hline $\begin{array}{l}\text { (9)Market } \\
\text { Capitalization }\end{array}$ & $.223^{* *}$ & $.194^{*}$ & .129 & .082 & -.088 & -.078 & -.129 & -.036 & 1 & & & \\
\hline $\begin{array}{l}\text { (10) Number of } \\
\text { Shareholders }\end{array}$ & $.382^{* *}$ & $.327^{* *}$ & $.315^{* *}$ & $.209^{*}$ & .139 & -.039 & -.003 & $-.183^{*}$ & $.309^{* *}$ & 1 & & \\
\hline $\begin{array}{l}\text { (11) Number } \\
\text { Subsidiaries }\end{array}$ & f. .046 & -.014 & -.035 & .018 & -.045 & -.008 & -.119 & .047 & $.259^{* *}$ & $.302^{* *}$ & 1 & \\
\hline $\begin{array}{l}\text { (12) Number } \\
\text { Employees }\end{array}$ & $\mathrm{f} .081$ & .163 & -.021 & -.104 & -.083 & -.057 & $-.171^{*}$ & $.185^{*}$ & .152 & .009 & .097 & 1 \\
\hline
\end{tabular}

Notes. Results are based on sample size of Malaysia $=16$, Japan $=64$, USA $=54$;

**. Correlation is significant at the 0.01 level (2-tailed).

*. Correlation is significant at the 0.05 level (2-tailed).

Table 6 illustrates the correlation coefficient between twelve variables. ROA recorded a strong relationship here with $r=.912$ compared to other variables. The significance values are less than 0.01 and 0.05 (as indicated by the asterisk after the coefficient). This significance values tells us that the probability of getting a correlation coefficient this big in a sample of 134 listed companies among those three countries. Referring the significance value, which below the standard criterion of .05 , indicating a 'statistically significant' relationship. From Table 6 also, we could conclude that liquidity ratio $(r=0.883)$ indicates a strong relationship after ROA, followed by ROCE $(r=.777)$, profit margin $(r=.674)$, solvency ratio $(r=.492)$, number of shareholders $(r=.309)$, number of subsidiaries $(r=.302)$ and current ratio $(r=.291)$.

By referring correlation analysis above, we could make a regression analysis number of shareholders and ROE over these three countries which recorded a significant value compared other variables as we can see.

Table 7. Linear regression coefficient of number of shareholders and ROE over three countries

\begin{tabular}{lllll}
\hline Model & $\begin{array}{l}\text { Standardized } \\
\text { Coefficients } \\
\text { Beta }\end{array}$ & $\mathrm{t}$ & Sig. \\
\hline \multirow{2}{*}{$\begin{array}{l}\text { (Constant) } \\
\text { Number of shareholders }\end{array}$} & .370 & 4.536 & .000 \\
\hline
\end{tabular}

a. Dependent Variable: ROE.

Table 7 show the linear regression coefficient of ROE and number of shareholders over those three countries. Beta $($ standardized regression coefficient $)=.370, \mathrm{t}(\mathrm{t}$-test of regression coefficient $)=4.505$, and the significant value is .000 .It can be conclude that, there is a positive linear correlation between ROE and number of shareholders over Malaysia, Japan and USA. In the other words, with the increasing in number of shareholders, 
ROE will increase too.

\section{Conclusions and Future Research}

The performance of the firms was analysed with respect to different perceptions by considering the data of profitability ratios, sales growth ratios and structures of the companies. On the other hand, the findings of the investigation provided a chance for all companies to judge their present condition and take decisions about their future steps while considering financial issues. To have a more reliable judgment about companies' performance, it could be of benefit to compare companies with their counterparts of the same business nature. In addition, the industry average can be taken into consideration. Indeed, a data-based study can be conducted to determine the most attractive company according to the same industry, which will examine whether profitability or market test ratios have more significant relationship with companies performance from other retail firms point of view.

From the findings obtained in this study, the results support the first hypothesis which stated that, sales growth rate of retail companies in Japan is better than the USA. Japan with free market economy is the third biggest in the world. Reported by U.S. Census Bureau (2015), Japan has the largest electronics industry and the third largest automobile industry in the world. Japan's economy is well-known by its efficiency and competitiveness in exports oriented sectors, but productivity is lower in areas such as agriculture, distribution, and variety of services including retailing. In contrast, retail sales in the USA decreased 0.90 per cent in December of 2014 over the previous month. Retail sales USA averaged 0.37 per cent from 1992 until 2014, reaching an all-time high of 6.71 per cent in October of 2001 and a record low of -3.58 per cent in October of 2008.

According to the analysis carried out, the results obtained were followed. As we can see, relationship among those three countries when performance of financial ratios and corporate variables are used as the dependent variables of each technique tested. According to Norman (2011), this result may be attributed to fighting international tax evasion, which becomes an important issue because it is a major source of illicit financial flows from developing countries. For example, Japan still mobilises less than $10 \%$ of their gross domestic product (GDP) in tax revenues. To combat tax crimes, effective exchange of information among countries is essential compared USA. This finding did not contribute to the second hypothesis, which stated that Japan and USA have a successful performance of financial ratios compared to Malaysia. This is because, Malaysia showed high means value for ROCE, ROA, profit margin, current ratio, liquidity ratio, solvency ratio and number of employees. While Japan showed the highest means value of sales growth rate and USA showed high means value of ROE, market capitalization, number of shareholders, and number of subsidiaries.

Through the correlation and regression analysis of ROE and number of shareholders over Malaysia, Japan and USA, one conclusion can be drawn which are as follows. With the increase in the number of shareholders, ROE are increased. So, this result supports our third hypothesis which stated that the number of shareholders influences the performance of ROE of the retailing companies.

We have considered different patterns of companies in terms of retail industry category in Malaysia, Japan and the USA. The role of each firm from each country is quite different. As previously discussed, Malaysia presents a very good performance and stable condition of financial performance, followed by the USA, which shows an outstanding result of others. Japan is a little bit low but is on their way to develop better structure of future foreseeable financial performance in the wake of "Abenomics", which has led to more dialogue on ways to improve returns. Furthermore, Japanese consumers have long been both distinctive and reassuringly predictable.

Future research could track the status of financial performance in other industry of several countries and compare the barriers of achieving high financial performance. Clearly, this study highlights the financial performance of those countries which is very limited and quite small in total due to the focusing period of 2008 to 2012. Therefore, it could be more interesting when it can be extended to an understanding of the distribution system that may be critical to successful exporting of knowledge of markets or products in several other countries. Another idea is to break down all establishments into a reasonable size of region where competition takes place, and conduct cross region analysis. An impact of the entry of large scale retailers in existing companies can be done with such data.

\section{Acknowledgements}

This study supported by JSPS KAKENHI Grant Number 24530500, Universiti Teknikal Malaysia Melaka (UTeM), and Ministry of Higher Education (MOHE), Malaysia. All errors and omissions are the responsibility of the authors.

\section{References}

Armitage, P., Berry, G., \& Matthews, J. N. S. (2001). Statistical Methods in Medical Research (4th ed.). 
Blackwell.

Asheghian, P. (2012). The Comparative Financial Managerial Performance of U.S. Firms and Chinese Firms. Journal of Finance and Investment Analysis, 1(2), 119-135.

Bjorson, K. (2013). Jones Lang LaSalle: E-commerce boom triggers transformation in retail logistics. Jones Lang LaSalle IP. INC.

Brunn, S. D. (2015). Wal-Mart World: The World's Biggest Corporation in the Global Economy. Routledge.

Bureau van Dijk Electronic Publishing. (2013). OSIRIS Database Manual. Bureau van Dijk Electronic Publishing, 44-53.

Farfan, B. (2014). All 2014 U.S. Retail Industry Store Openings, Domestic \& International Largest U.S. Retail \& Restaurant Chains Opening New Locations Wordwide in 2014. Retrieved from http://retailindustry.about.com/od/storeclosingsandopenings/fl/All-2014-US-Retail-Industry-Store-Openings -Domestic-amp-International.htm

Field, A. (2013). Discovering Statistics Using IBM SPSS Statistics (4th ed.). SAGE Publications Inc.

Gazzola, P., \& Amelio, S. (2014). The Impact of Comprehensive Income on the Financial Ratios in a Period of Crises. Procedia Economics and Finance, 12, 174-183. http://dx.doi.org/10.1016/S2212-5671(14)00333-5

Harvard Business Review Group. (2013). The Impact of Employee Engagement on Performance. Harvard Business Review Analytic Services report. Retrieved from https://hbr.org/resources/pdfs/comm/achievers/hbr_achievers_report_sep13.pdf

Higón, D. A., Bozkurt, Ö., Clegg, J., Grugulis, I., Salis, S., Vasilakos, N., \& Williams, A. M. (2010). The Determinants of Retail Productivity: A Critical Review of the Evidence. International Journal of Management Reviews, 12(2), 201-217. http://dx.doi.org/10.1111/j.1468-2370.2009.00258.x

Kearney, A. T. (2014). Full Steam Ahead for Global Retailers: The 2014 Global Retail Development Index. Retrieved

from http://www.atkearney.com/consumer-products-retail/global-retail-development-index/full-report

Korotayev, A., Zinkina, J., Bogevolnov, J., \& Malkov, A. (2011). Global Unconditional Convergence among Larger Economies after 1998? Journal of Globalization Studies, 2(2), 25-62.

Kudo, M. (2014). Nikkei Asian Review: Aeon Aims At 1 Trillion Yen in Non-Japan Asia Sales. Retrieved from $\mathrm{http}$ //asia.nikkei.com/magazine/20140612-BORDERLESS-ASEAN/Business/Aeon-aims-at-1-trillion-yen-i n-non-Japan-Asia-sales

McEnally, R. W. (1976). Competition and Dispersion in Rates of Return. Journal of Industrial Economics, 25(1), 69-75. http://dx.doi.org/10.2307/2097898

Mohamad, N., \& Hoshino, Y. (2013). Host Country Restrictions, Choice of Entry Mode and Japanese Subsidiaries Performance in Developing Countries. American Journal of Economies, 3(1), 12-17.

Norman, A. S. (2011). Financial Analysis as a Consideration for Stock Exchange Investment Decisions in Tanzania. Journal of Accounting and Taxation, 3(4), 60-69.

Paul, A. K. (2014). 2015 Retail Industry Outlook. Retrieved from http://deloitte.wsj.com/cio/2014/12/22/2015-retail-industry-outlook/

PWC. (2015). Retailing 2015: New Frontiers. Retrieved from https://www.pwc.com/es_CL/cl/publicaciones/assets/retailing2015.pdf

Rayley T., \& Benton, E. G. (2010). Valuation Techniques from Today's Top Practitioners. The Valuation Handbook of Finance. John Wiley \& Sons, Inc.

Ross, S. A., Westerfield, R. W., \& Jaffe, J. (2005). Corporate Finance (7th ed.). McGraw-Hill Inc.

Sam, M. F. M., \& Hoshino, Y. (2013). Performance of ICT Industry in Six Asian Countries. International Journal of Business Administration, 4(6), 96-119.

Tabachnick, B. G., \& Fidell, L. S. (2012). Using Multivariate Statistics (6th ed.). Boston, MA: Pearson/Allyn \& Bacon.

U.S. Census Bureau. (2015). Trading Economics: United States Retail Sales of. Retrieved from http://www.tradingeconomics.com/

Varaiya, N., Kerin, R. A., \& Weeks, D. (1987). The Relationship between Growth, Profitability, and Firm Value. 
Strategic Management Journal, 8(5), 487-497. http://dx.doi.org/10.1002/smj.4250080507

Yalcin, N., Bayrakdaroglu, A., \& Kahraman, C. (2012). Application of Fuzzy Multi-Criteria Decision Making Methods for Financial Performance Evaluation of Turkish Manufacturing Industries. Expert Systems with Applications, 39(1), 350-364. http://dx.doi.org/10.1016/j.eswa.2011.07.024

Yap, B. C. F., Munuswamy, S., \& Mohamed, Z. (2012). Evaluating Company Failure in Malaysia Using Financial Ratios and Logistic Regression. Asian Journal of Finance \& Accounting, 4(1), 330-344. http://dx.doi.org/10.5296/ajfa.v4i1.1752

\section{Appendix A - Listed Companies}

Malaysia

\begin{tabular}{llllll}
\hline 1. & Parkson Holdings Berhad & 2. & Mbm Resources Bhd & 3. & The Store Corporation Berhad \\
\hline 4. & Atlan Holdings Bhd & 5. & Padini Holdings Berhad & 6. & Cycle \& Carriage Bintang Berhad \\
7. & Tomei Consolidated Berhad & 8. & Bonia Corporation Bhd & 9. & Suiwah Corporation Bhd \\
10. & Hai-O Enterprise Berhad & 11. & Fiamma Holdings Bhd & 12. & Kamdar Group (M) Berhad \\
13. & Cni Holdings Berhad & 14. & Marco Holdings Berhad & 15. & Teo Guan Lee Corporation Bhd \\
16. & Fcw Holdings Bhd & & & & \\
\hline
\end{tabular}

\section{Japan}

\begin{tabular}{|c|c|c|}
\hline Seven \& I Holdings Co., Ltd. & Kirin Holdings Co., Ltd. & Japan Tobacco Inc \\
\hline Asahi Group Holdings Ltd. & Yamada Denki Co Ltd & J. Front Retailing Co. Ltd. \\
\hline Fast Retailing Co Ltd & Yamazaki Baking Co Ltd & Nippon Meat Packers Inc \\
\hline 10. Takashimaya Company Limited & 11. Kato Sangyo Co Ltd & 12. Paltac Corporation \\
\hline 13. Bic Camera Inc. & 14. Shiseido Company Limited & 15. K's Holdings Corp. \\
\hline 16. Itochu-Shokuhin Co Ltd & 17. Morinaga Milk Industry Co Ltd & 18. Kewpie Corporation \\
\hline 19. Don Quijote Co. Ltd. & 20. Izumi Co Ltd & 21. Sapporo Holdings Limited \\
\hline 22. H2o Retailing Corp. & 23. Shimamura Co Ltd & 24. Lawson Inc \\
\hline 25. Unicharm Corporation & 26. Nichirei Corporation & 27. Matsumotokiyoshi Holdings Co Ltd \\
\hline 28. Nisshin Seifun Group Inc & 29. Dem Holdings Co., Ltd. & 30. Arcs Co., Ltd. \\
\hline 31. Valor Co Ltd & 32. Heiwado Co Ltd & 33. Ito En Ltd \\
\hline 34. Nissin Food Holdings Co., Ltd. & 35. At-Group Co., Ltd. & 36. Joshin Denki Co Ltd \\
\hline 37. Lion Corporation & 38. Nitori Holdings Co., Ltd. & 39. Sugi Holdings Co., Ltd. \\
\hline 40. Toyo Suisan Kaisha Ltd & 41. Family Mart Co Ltd & 42. The Maruetsu Inc \\
\hline 43. Tsuruha Holdings Inc & 44. Komeri Co Ltd & 45. Yakult Honsha Co Ltd \\
\hline 46. Yamae Hisano Co., Ltd. & 47. Nisshin Oillio Group Ltd. & 48. Cosmos Pharmaceutical Corporation \\
\hline 49. Okuwa Co Ltd & 50. Kikkoman Corporation & 51. Kohnan Shoji Co Ltd \\
\hline 52. Prima Meat Packers Ltd & 53. Parco Co Ltd & 54. Nippon Flour Mills Co Ltd \\
\hline 55. Maxvalu Nishinihon Co., Ltd. & 56. Geo Holdings Corporation & 57. Aeon Kyushu Co., Ltd. \\
\hline 58. Starzen Company Limited & 59. Yaoko Co Ltd & 60. Kasumi Co Ltd \\
\hline 61. Cawachi Limited & 62. Showa Sangyo Co Ltd & 63. Nafco Co Ltd. \\
\hline 64. Autobacs Seven Co Ltd & & \\
\hline
\end{tabular}

USA

\begin{tabular}{lll} 
1. Wal-Mart Stores, Inc & 2. Costco Wholesale Corp & 3. Kroger Co \\
4. Home Depot Inc & 5. Target Corp & 6. Amazon.Com, Inc \\
7. Lowe's Companies, Inc & 8. Sysco Corp & 9. Tjx Companies Inc \\
10. Staples Inc & 11. Kohls Corporation & 12. Genuine Parts Co \\
13. Nordstrom Inc & 14. Carmax Inc & 15. L Brands, Inc \\
16. Family Dollar Stores, Inc & 17. Liberty Interactive Corporation & 18. Ross Stores Inc \\
19. Core-Mark Holding Company, Inc & 20. Gamestop Corp & 21. Caseys General Stores Inc \\
22. Reilly Automotive Inc & 23. United Natural Foods Inc & 24. Susser Holdings Corporation \\
25. Big Lots, Inc & 26. Andersons Inc & 27. Ascena Retail Group, Inc \\
\hline
\end{tabular}




\begin{tabular}{lll}
\hline 28. Harris Teeter Super Markets Inc & 29. Abercrombie \& Fitch Co & 30. Lkq Corporation \\
31. Tiffany \& Co & 32. Ingles Markets Inc & 33. Cabela's Incorporated \\
34. Spartan Stores Inc & 35. Genesco Inc & 36. Mens Wearhouse Inc \\
37. Hhgregg, Inc & 38. Ulta Salon & 39. Cosmetics \& Fragrance, Inc \\
40. Pricesmart Inc & 41. Village Super Market Inc & 42. Freds Inc \\
43. The Fresh Market Inc & 44. Amcon Distributing Co & 45. Jos. A. Bank Clothiers, Inc \\
46. Cato Corp & 47. Big 5 Sporting Goods Corporation & 48. Hibbett Sports Inc \\
49. Shoe Carnival Inc & 50. Monro Muffler Brake Inc & 51. Shutterfly, Inc \\
52. China Auto Logistics Inc & 53. Wet Seal Inc & 54. America's Car-Mart, Inc \\
\hline
\end{tabular}

Abbreviation:

INC - Incorporation;

PLC - Public Company Limited;

CO LTD - Company Limited;

CORP - Corporation;

LTD - Limited.

\section{Copyrights}

Copyright for this article is retained by the author(s), with first publication rights granted to the journal.

This is an open-access article distributed under the terms and conditions of the Creative Commons Attribution license (http://creativecommons.org/licenses/by/3.0/). 